\title{
PEMBELAJARAN FISIKA MELALUI LESSON STUDY BERBASIS INKUIRI UNTUK MENINGKATKAN KEMAMPUAN MENGAJAR PENDIDIK DAN HASIL BELAJAR PESERTA DIDIK
}

\author{
Muhammad Satriawan \\ Program Studi Pendidikan Fisika STKIP Bima \\ E-mail: satriawan.stkipbima@gmail.com
}

Penelitian ini bertujuan untuk meningkatkan kemampuan mengajar pendidik dan hasil belajar peserta didik. Jenis penelitian ini adalah penelitian tindakan yang dilaksanakan melalui tahap perencanaan, pelaksanaan, dan refleksi dengan 2 siklus. Subjek penelitian ini adalah MA Putri Nurul Hakim dengan jumlah peserta didik 25 orang. Teknik analisis data menggunakan statistik deskriptif untuk menggambarkan kemampuan mengajar pendidik dan peningkatan hasil belajar peserta didik. Hasil penelitian menunjukkan bahwa pada siklus I kemampuan mengajar pendidik berkategori baik, selain itu diperoleh bahwa secara klasikal ketuntasan hasil belajar peserta didik hanya mencapai 60\% dengan nilai rata-rata 69 yang artinya pembelajaran dapat dikatakan belum tuntas karena ketuntasan kurang dari $85 \%$. Sedangkan pada siklus II kemampuan pedogogik pendidik berkategori baik dan secara klasikal ketuntusan hasil belajar peserta didik mencapai $92 \%$ dengan nilai rata-rata 80,92 yang artinya pembelajaran dapat dikatakan tuntas karena ketuntasan lebih dari $85 \%$. Dengan demikian/dapat disimpulkan bahwa terjadi peningkatan kemampuan mengajar pendidik dan hasil belajar peserta didik dari siklus I ke siklus II pada pembelajaran melaui lesson study berbasis inkuiri.

Kata Kunci: Lesson Study, Inkuiri, Kemampuan Mengajar, Hasil Belajar.

\section{ABSTRACT}

This study aims to improve teaching ability of educators and learning outcomes of students. This type of research is action research conducted through the planning, implementation and reflection with 2 cycles. The subjects were MA Putri Nurul Hakim the number of learners 25 people. Data were analyzed using descriptive statistics to describe the teaching abilities of educators and improvement of learning outcomes of students. The results showed that in the first cycle capability pedagogic of educators-categorized medium teaching ability, other than was found that classically completeness learning outcomes of students only reached $60 \%$ with an average value of 69, that means learning can be said to be unfinished because of the thoroughness of less than $85 \%$. While in the second cycle capability pedagogic of educators categorized good teaching ability, other than was found that classically completeness learning outcomes of students reached $92 \%$ with an average value of 80.92 , that means learning can be said to be complete because of the thoroughness of more than $85 \%$. Thus it can be concluded that an increase teaching ability of educators and learning outcomes of students from the first cycle to the second cycle on learning through inquiry-based lesson study.

Keywords: Lesson Study, Inquiry, Teaching Capability, Learning Outcomes.

\section{PENDAHULUAN}

Didalam pembukaan UUD 1945 alinea ke-4 tercantum tujuan pendidikan nasional Negara Republik Indonesia. Salah satu tujuan itu adalah "Mencerdaskan Kehidupan Bangsa". Selanjutnya dalam UU No. 2 Tahun 1989 tentang Sistem Pendidikan Nasional disebutkan bahwa Pendidikan Nasional Indonesia berdasarkan Pancasila yang bertujuan untuk meningkatkan ketaqwaan kepada Tuhan Yang Maha Esa, kecerdasan dan keterampilan, mempertinggi budi pekerti, memperkuat kepribadian dan mempertebal semangat kebangsaan agar dapat menumbuhkan manusia-manusia pembangunan yang bertanggung jawab atas pembangunan bangsa.

Untuk mencapai tujuan tersebut, maka pemerintah melalui Departemen Pendidikan Nasional senantiasa berusaha untuk mencetak tenaga pengajar yang 
profesional dibidangnya. Dalam hal ini pendidik mempunyai tugas dan peranan yang sangat penting. Tugas seorang pendidik tidak hanya memberikan pengetahuan kepada peserta didik tetapi lebih dari itu, pendidik juga turut membentuk pribadi anak didik agar menjadi manusia pembangunan sesuai dengan yang dinyatakan dalam falsafah negara yaitu Pancasila dan UUD 1945. Dengan kata lain, seorang pendidik harus benar-benar profesional dan memiliki kualitas agar mampu melaksanakan tugas-tugasnya.

Untuk menjadi seorang pendidik yang berkualitas perlu adanya pembinaan dalam pembelajaran yang dilakukan. Selama ini, pembelajaran yang dilakukan oleh guru tidak terekam dengan baik dan refleksi proses pembelajaran pun hanya bersumber dari guru seorang, tidak dari guru yang lain. Hal itu perlu adanya pembinaan yang tepat untuk meningkatkan kualitas pembelajaran. Pembinaan yang tepat tersebut adalah dengan menerapkan lesson study.

Lesson study merupakan bentuk pengembangan profesional pendidik yang awal mulanya berasal dari Jepang. Berdasarkan laporan Third International Mathematics and Science Study (TIMSS) pada tahun 1996, peserta didik Jepang memiliki rangking lebih tinggi dalam bidang fisika. Hal ini diduga karena akibat diterapkannya lesson study (jugyokenkyu) di sekolah (Wang-Iverson, 2002). Dengan melaksanakan lesson study memungkinkan pendidik untuk mengkaji dan mengembangkan pembelajaran yang terbaik, memperdalam materi yang akan dibelajarkan, dan sebagai wahana belajar membelajarkan peserta didik. Di samping itu, lesson study dapat menyediakan kesempatan yang penting bagi para pendidik melakukan eksplorasi dan cara yang efektif menggunakan papan tulis untuk meningkatkan penalaran (thinking) dan pemahaman peserta didik (Yosida, 2002).

Lesson study is a professional development process that Japanese teachers engage in to systematically examine their practice (Fernadez et al., 2001). Lesson study is a cycle in which teachers work together to consider their long-term goals for students, bring those goals to life in actual "research lessons," and collaboratively observe, discuss, and refine the lessons (Lewis, 2002). Lesson study merupakan suatu proses sistematis yang digunakan oleh guru-guru di Jepang untuk menguji keefektifan guruannya dalam rangka meningkatkan hasil pembelajaran (Garfield, 2006). Proses sistematis yang dimaksud adalah kerja guru-guru secara kolaboratif untuk mengembangkan rencana dan perangkat pembelajaran, melakukan observasi, refleksi dan revisi rencana pembelajaran secara bersiklus dan terus menerus. Walker (2005) menyatakan bahwa lesson study adalah suatu pengembangan profesional guru. Lewis (2002) menyebutkan bahwa lesson study merupakan gagasan yang sederhana. Jika guru ingin meningkatkan instruksi dalam pembelajaran, maka guru haruslah bekerja sama dengan guru lainnya dalam merencanakan, mengamati, dan proses refleksi.

Marsigit (2007) menyatakan bahwa tujuan dari kegiatan lesson study adalah: (1) untuk mengembangkan instrumen dan peralatan untuk proses belajar mengajar, (2) untuk mengembangkan metode dan model pembelajaran untuk proses belajar mengajar, (3) untuk mengembangkan materi mengajar untuk proses belajar mengajar, dan (4) untuk mengembangkan evaluasi mengajar untuk proses belajar mengajar. Dengan demikian, profesionalisme guru dapat terwujud secara utuh.

Untuk dapat terlaksananya lesson study dengan baik dan berhasil, ada lima sikap positif pendidik yang harus dimiliki oleh pendidik, yaitu (1) memiliki semangat mengkritik diri sendiri; (2) terbuka menerima masukan dari orang lain; (3) mau mengakui kesalahan; (4) menerima ide orang lain; dan (6) mau memberi masukan yang jujur dan penuh respek. Adapun tahapan pelaksanan lesson study yang telah dikembangkan bervariasi. Berikut ini akan dipaparkan tahapan pelaksanaan lesson study menurut Fernandez \& Yoshida (2004), merancang lesson study, mengamati, membelajaran peserta didik dengan versi baru pembelajaran dan berbagi hasil refleksi mengenai versi baru pembelajaran. Lesson study yang dikembangkan Saito, et al. (2005) terdiri dari tiga tahapan yaitu perencanaan (Plan), pelaksanaan (Do), refleksi (See).

Berdasarkan uraian di atas nampak bahwa lesson study merupakan suatu kegiatan yang mampu meningkatkan kualitas seorang pendidik. Oleh karena itu, perlu adanya suatu model atau metode lain yang harus dikolaborasikan dalam kegiatan lesson study dengan tujuan untuk meningkatkan kualitas pembelajaran sehingga memberikan dampak positif kepada peserta didik baik dari segi kognitif, psikomotorik dan afektif. Salah satu metode yang dapat digunakan adalah metode inkuiri.

Pembelajaran berbasis inkuiri adalah pembelajaran dimana peserta-didik menemukan dan menggunakan berbagai macam sumber-sumber informasi dan ide-ide untuk menambah pemahaman mereka tentang suatu masalah, topik atau isu (Kuhlthau, Maniotes \& Caspari, 2007). Pembelajaran ini yang menekankan pada proses berfikir secara kritis dan analitis untuk mencari dan menemukan sendiri jawaban dari suatu masalah yang dipertanyakan. Proses berfikir itu sendiri biasanya dilakukan melalui tanya jawa antara guru dan peserta didik. Dengan kata lain, inkuiri adalah suatu proses untuk memperoleh dan mendapatkan informasi dengan melakukan observasi dan atau eksperimen untuk mencari jawaban atau memecahkan masalah terhadap pertanyaan atau rumusan masalah dengan menggunakan kemampuan berpikir kritis dan logis.

Metode Inquiry melibatkan peserta didik secara aktif dalam pembelajaran yang kolaboratif dan keterampilan sosial, dan meminta kerjasama peserta didik dari hasil yang dicapai dalam proses pembelajaran sedangkan guru membantu peserta didik memahami asumsi apapun yang dikemukakan. Bell at al (2005) menyatakan ada empat tahap dalam pembelajaran inquiry, yaitu: confirmation inquiry, structured inquiry, guided inquiry, open inquiry. Empat tahapan tersebut menjadikan peserta didik terlibat aktif dalam proses pembelajaran. Metode inkuiri juga merupakan metode pembelajaran yang dalam penyampaian bahan pelajarannya tidak dalam bentuknya yang final, atau dalam artian tidak langsung. Artinya, dalam penyampaian metode inkuiri peserta didik sendirilah yang diberi peluang untuk mencari (menyelidiki/meneliti) dan memecahkan sendiri jawaban 
(permasalahan) dengan mempergunakan teknik pemecahan masalah. Namun demikian pengajar bertindak sebagai pengarah, mediator, dan fasilitator, yang wajib memberikan informasi yang relevan, sesuai dengan permasalahan atau materi pelajaran. Hal tersebut dapat berlangsung dalam kelompok-kelompok kecil dalam kelas melalui diskusi dan bermain peran. Dalam kegiatan ini peserta didik dituntut aktif terlibat dalam situasi belajar. Peserta didik menyadari masalah, mengajukan pertanyaan, selanjutnya menghimpun informasi sebelum mengambil keputusan (Munandar, 1995: 85). Dengan demikian sangat jelas metode inkuiri memberikan kebebasan yang besar pada peserta didik untuk mengembangkan dirinya, meskipun tidak terlepas dari peranan guru dalam memimpin, membimbing, dan memberi arahan dalam proses pembelajaran. Pada dasarnya peserta didik mampu mengembangkan kemampuan berpikir, dan juga dengan strategi penemuan untuk menyelesaikan masalah, mengkomunikasikan ide dan hasil temuan, bekerja secara kolaboratif dan membuat kesimpulan. Kemampuan peserta didik tersebut memerlukan suatu perencanaan pembelajaran yang baik, dalam hal ini strategi pembelajaran inkuiri menjadi alternatif dalam mengeksplorasi kemampuan peserta didik.

Menurut Khan (2012) pengajaran berbasis penyelidikan (inquiry) di kelas fisika memberikan kesempatan peserta didik untuk belajar lebih aktif dalam ruang kelas, meningkatkan interaksi sosial dan pengembangan intelektual dalam proses pembelajaran. Sebagai strategi pembelajaran, Jinkuiri dapat diimplementasikan secara terpadu dengan strategi lain sehingga dapat membantu pengembangan pengetahuan dan pemahaman serta kemampuan melakukan/kegiatan inkuiri oleh peserta didik. Strategi pembelajaran inkuiri dapat digunakan untuk meningkatkan proses pembelajaran peserta didik, dan dapat disesuaikan dengan tujuan yang ingin dicapai oleh pembelajaran pada berbagai mata pełajaran, khusúsnya fisika, yaitu meliputi aspek: kemampuan mengemukakan pendapat, kemampuan menganalisa masalah, kemampuan menuliskan pendapatnya setelah melakukan pengamatan, dan kemampuan menyimpulkan.

Pembelajaran dengan inkuiri tidak hanya mengembangkan kemampuan intelektual tetapi seluruh potensi yang ada, termasuk pengembangan emosional dan pengembangan keterampilan. Discovery learning, inqiury-based learning dan problem-based learning semuanya menggambarkan pengalaman peserta didik saat bergulat dengan pertanyaan atau masalah, berpartisipasi dalam langkah-langkah menyelesaikan masalah dan mengkomunikasikan apa yang mereka temukan kepada orang lain (Dell'Olio \& Tony Donk, 2007). Di dálàm metode pembelajaran inkuiri peserta didik dihadapkan pada sebuah masalah yang dibuat oleh guru, sehingga peserta didik harus berusaha secara aktif dengan kemampuan dan keterampilannya untuk mendapatkan menghasilkan penyelesaian dari masalah yang dihadapinya. Dengan metode pembelajaran inkuiri akan melatih peserta didik berani mengemukakan pendapat dan menemukan sendiri pengetahuannya yang berguna untuk memecahkan masalah yang dihadapinya. Adapun tujuan dalam penelitian ini adalah untuk mendeskripsikan dan menganalisa keterlaksanaan lesson study berbasis inkuiri pada peserta didik SMA.

\section{METODE PENELITIAN}

Penelitian ini merupakan penelitian deskriptif dengan menerapkan lesson study berbasis inkuiri di MA Putri Nurul Hakim. Penelitian ini dilaksanakan dalam dua siklus untuk melihat keterlaksanaan pembelajaran dengan metode inquiry yang dapat memahamkan peserta didik mengenai materi hukum newton. untuk mengetahui faktor-faktor yang mendukung dan menghambat dalam pelaksanaan lesson study di MA Putri Nurul Hakim. Peneliti beserta rekan yang tergabung dalam kelompok lesson study berkolaborasi untuk mengembangkan rencana dan perangkat pembelajaran, melakukan observasi, refleksi dan revisi rencana pembelajaran pada siklus 1 dan dilanjutkan ke siklus 2 yang merupakan perbaikan pembelajaran pada siklus 1. Peneliti bertindak sebagai guru model dan rekan sekelompok bertindak sebagai observer. Subjek dalam penelitian ini adalah peserta didik kelas X MA Putri Nurul Hakim yang terdiri dari 25 peserta didik. Untuk memantau aktivitas peserta didik selama kegiatan lesson study, digunakan lembar observasi yang diisi oleh observer. Hal-hal yang perlu dicatat dalam lembar observasi berupa aktivitas peserta didik secara detail ketika pembelajaran berlangsung, mulai dari kegiatan awal, kegiatan inti, hingga kegiatan penutup.

Adapun tahapan kegiatan dalam penelitian ini adalah melewati tahapan perencanaan, pelaksanaan dan refleksi. Untuk mendapatkan gambaran tebih jelas dapat dilihat pada Gambar berikut:

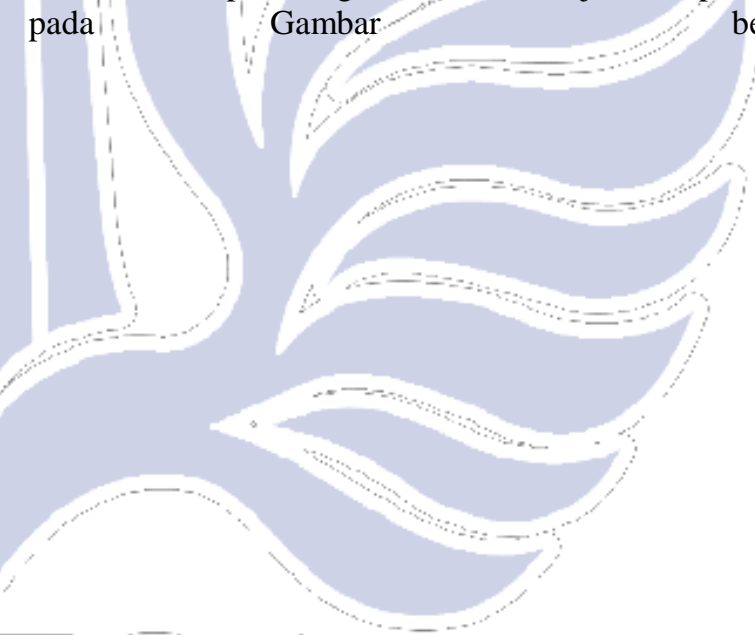




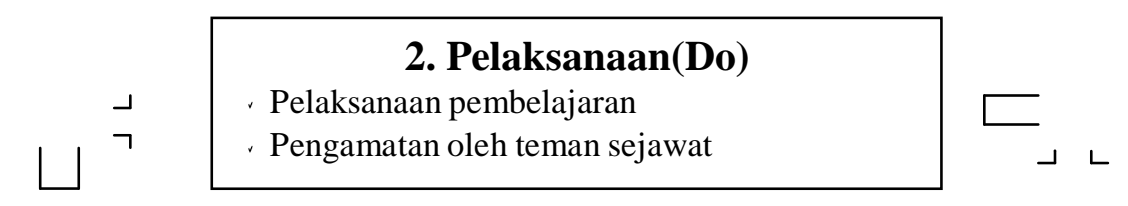

1. Perencanaan(Plan)
. Penggalian akademis
. Perencanaan pembelajaran
Persiapan alat

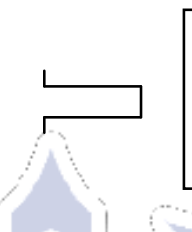
3. Refleksi (See)
Refleksi dengan rekan
Komentar dan diskusi

Gambar 1. Daur Studi Pembelajaran Terorientasi pada Praktik (Diadaptasikan dari Sutopo \& Ibrohim, 2006)

\section{HASIL DAN PEMBAHASAN \\ Hasil Penelitian}

Pada pelaksanaan penelitian terdiri dari 2 siklus yang masing-masing siklus terdapat 3 tahapan yaitu plan, do, dan refleksi . Dari ketiga tahap tersebut masing-masing memiliki hasil yaitu:

Siklus I

\section{Tahap Plan}

Pada tahap plan diperoleh hasil berupa instrumen penelitian dan siap digunakan dalam Tabel 1. Hasil belajar siklus 1 proses belajar mengajar. Adapun hasil yang diperoleh pada tahap ini yaitu:

a) Rencana pelaksanaan pembelajaran (RPP);

b) Lembar kegiatan peserta didik (LKS);

c) Lembar observasi open class-lesson study.

\section{Tahap Do}

Adapun hasil belajar peserta didik yang dipeoleh/dari evaluasi pada akhir pembelajaran yaitu;

\begin{tabular}{|c|c|c|c|c|c|}
\hline $\mathrm{NO}$ & NAMA & NILAI & $\mathrm{NO}$ & NAMA & NHLAI \\
\hline 1 & Agnia Savitri & 78 & 16 & Niswatin Asparini & 28 \\
\hline 2 & Ana Erma Wati & 78 & 17 & Pahmi Wati & 68 \\
\hline 3 & Bq Emi Andriyani & 63 & 18 & Putri Artiati & 78 \\
\hline 4. & Baiq Nuzuliah & 68 & 19 & Ramdani Indah Y & 70 \\
\hline $5=$ & Desi Januardani & 78 & 20 & Sakmah & 72 \\
\hline 6 & Dewi Yuliana & 78 & 21 & Sopiatul Hidayat & 63 \\
\hline 7 & Hidayatusholehah & 63 & 22 & Sri Wedari & 65 \\
\hline 8 & Ida Susanti & 78 & 23 & Suciyatul Fahmi & 72 \\
\hline 9 & Jumratul Hasanah & 73 & 24 & Suhaeniah & $=63$ \\
\hline 10 & Laela Indriyani & 65 & 25 & Ulfa Hidayah & 78 \\
\hline 11 & Lia Apriyani & 70 & & JUMLAH NILAI & 1725 \\
\hline 12 & Maesharah & 48 & & ATA-RATA NHLAI & 69 \\
\hline 13 & Muliani & & & $\begin{array}{l}\text { LAH PESERTA DIDIK } \\
\text { TUNTAS }\end{array}$ & 15 \\
\hline 14 & Munawarah & 75 & & TUNTASAN KELAS & $60 \%$ \\
\hline 15 & Nidaan Khafiah & 78 & & $\sqrt{K K M}=70$ & \\
\hline
\end{tabular}

\section{Tahap Refleksi}

Pada tahap ini diperoleh hasil berupa data deskriptif mengenai temuan-temuan oleh Obserever.

a. Observer I (Rumansyah, S.Pd)

Observer I mengamati 4 orang peserta didik yaitu Zulfaidah, Munawarah, Nurasiah, dan Desi. Adapun temuan-temuan oleh observer selama berlangsungnya proses pembelajaran yaitu:
1) Pada awal pembelajaran suasana kelas cukup panas sehingga mempengaruhi keadaan peserta didik

2) Peserta didik cukup antusias menerima materi pembelajaran yang dapat dilihat ketika pendidik memberikan pertanyaan, peserta didik langsung menjawabnya

3) Dari ke empat peserta didik terdapat dua peserta didik yang paling aktif yaitu Desi dan Zulfaidah 
4) Pada saat percobaan, keempat peserta didik tersebut mencoba sendiri-sendiri karena alat yang dipersiapkan oleh pendidik model hanya satu dalam satu kelompok

5) Pendidik model membantu peserta didik yang mengalami kesulitan

6) Pada saat evaluasi, keempat peserta didik bekerjasama dimana jawaban Desi dilihat oleh ketiga temannya yang lain.

7) Metode inkury yang digunakan belum nampak.

b. Observer II (Sugiman, S.Pd)

Adapun temuan-temuan oleh observer selama berlangsungnya proses pembelajaran yaitu:

1) Pada saat pendidik model menjelaskan, suasana kelas cukup panas sehingga mempengaruhi pikiran anak dalam menerima pelajaran.

2) Pada saat percobaan, peserta didik memotong karet karena tidak tahu apa yang mestinya dilakukan.

3) Pada saat evaluasi, peserta didik menjawab soal dengan mencari-cari jawaban di buku.

4) Peserta didik yang semulanya pasif namun pada akhirnya menjadi aktif.

c. Observer III (Anwar Suhudy, S.Pd)

Adapun temuan-temuan oleh observer selama berlangsungnya proses pembelajaran yaitu:

1) Sejak awal pembelajaran suasana kelas terlalu panas sehingga peserta didik tidak nyaman dalam mengikuti pembelajaràn.

2) Peserta didik selalu-memperhatikan pendidiknya dalam artian tidak sepenuhnya memahami apa yang pendidik model sampaikan dikarenakan semua peserta didik perempuan sedangkan pendidik modelnya laki-laki dan masih muda
3) Pada saat mengobservasi, observer kesulitan membaca nama peserta didik dikarenakan papan nama peserta didik tidak terlalu besar

4) Pada saat percobaan, peserta didik bekerja asalasal saja tidak tahu harus memulai darimana.

d. Observer IV (Yuyu Sudarmini, S.Pd)

Adapun temuan-temuan oleh observer selama berlangsungnya proses pembelajaran yaitu:

1) Pada saat pendidik model menjelaskan keadaan peserta didik secara keseluruhan cukup aktif

2) Pada awal pembelajaran peserta didik kurang fokus memperhatikan apa yang dijelaskan oleh pendidik model

3) Pada saat percobaan, peserta didik terlihat kurang aktif dikarenakan LKS hanya satu

4) Pada saat evaluasi, peserta didik hanya meremasremas kartu namanya.

\section{Siklus II}

\section{Tahap Plan}

Pada tahap plan diperoleh hasil berupa intrument penelitian yang telah direvisi berdasarkan hasil refleksi siklus I dan siap digunakan dalam proses belajar mengajar. Adapun hasil yang diperoleh pada tahap ini yaitu:
a) Rencana pelaksanaan pembelajaran (RPP);
b) Lembar kegiatan peserta didik (LKS);

\section{Tahap Do}

Adapun hasil belajar peserta didik yang dipeoleh dari eyaluasi pada akhir pembelajaran yaitu;

Tabel 2. Hasil belajar siklus II

\begin{tabular}{|c|c|c|c|c|c|}
\hline NO & NAMA & NILAI & NO & NAMA & NILAI \\
\hline 1 & Agnia Savitri & 87 & 16 & Niswatin Asparini & 43 \\
\hline 2 & Ana Erma Wati & 83 & 17 & Pahmi Wati & 82 \\
\hline 3 & Bq Emi Andriyani & 77 & 18 & Putri Artiati & 93 \\
\hline 4 & Baiq Nuzuliah & 78 V & 19 & Ramdani Indah Y & 82 \\
\hline 5 & Desi Januardani & 92 & 20 & Sakmah & 78 \\
\hline 6 & Dewi Yuliana & 88 & 21 & Sopiatul Hidayat & 77 \\
\hline 7 & Hidayatusholehah & 77 & 22 & Sri Wedari & 74 \\
\hline 8 & Ida Susanti & 93 & 23 & Suciyatul Fahmi & 82 \\
\hline 9 & Jumratul Hasanah & 87 & 24 & Suhaeniah & 78 \\
\hline 10 & Laela Indriyani & 78 & 25 & Ulfa Hidayah & 92 \\
\hline 11 & Lia Apriyani & 82 & \multicolumn{2}{|r|}{ JUMLAH NILAI } & 2023 \\
\hline 12 & Maesharah & 63 & \multicolumn{2}{|c|}{ RATA-RATA NILAI } & 80,92 \\
\hline 13 & Muliani & 82 & \multicolumn{2}{|c|}{$\begin{array}{c}\text { JUMLAH PESERTA DIDIK } \\
\text { TUNTAS }\end{array}$} & 23 \\
\hline 14 & Munawarah & 83 & \multicolumn{2}{|c|}{ KETUNTASAN KELAS } & $92 \%$ \\
\hline 15 & Nidaan Khafiah & 92 & \multicolumn{3}{|c|}{ KKM $=70$} \\
\hline
\end{tabular}




\section{Tahap Refleksi}

Pada tahap ini diperoleh hasil berupa data deskriptif mengenai temuan-temuan oleh Obserever yang dapat dirangkum sebagai berikut:

a. Kesiapan belajar peserta didik tergolong baik.

b. Respon peserta didik terhadap proses pembelajaran yang dilakukan oleh peneliti tergolong baik, hal ini terlihat dari beberapa kelompok mampu menemukan sendiri jawaban dari permasalahan

c. Interaksi peserta didik dengan peneliti tergolong aktif. Hal ini dapat dilihat dari keaktifan peserta didik dalam menjawab beberapa pertanyaan dari peneliti, bertanya kepada peneliti apabila peserta didik mengalami kesulitan dalam menemukan pemecahan dari permasalahan yang diberikan

d. Interaksi peserta didik dengan peserta didik lain juga tergolong baik. Hal ini dapat dilihat daribeberapa peserta didik yang menemukan jawaban permasalahan mendiskusikan dan memberitahukan kepada teman lainnya yang belum bisa.

e. Keterlaksanaan metode inkuiri sudah nampak dan berjalan lancar.

\section{PEMBAHASAN}

Pelaksanaan pendidik modelan dilakukan di dua tempat yaitu di FKIP Unram (tahap plan dan refleksi) dan di MA Putri Nurul Hakim (tahap do). Kegiatan ini bermaksud selain untuk meningkatkan hasil belajar peserta-didik kegiatan ini bertujuan untuk meningkatkan profesioanalisme seorang pendidik dalam bidang pembelajaran secara berkelanjutan. Hat itu dapat dilakukan dengan mengumpulkan bukti-bukti yang diperoleh dari pelaksanaan mengenai kekurangan atau pun kelebihan seorang pendidik ketika mengajar. Dari bukti-bukti tersebutlah pendidik dapat melihat seberapa profesionalkah dirinya-dalam mengajar dan apabila ditemukan kejanggalan-kejanggalan maka dengan segera dapat diperbaiki.

Pada siklus I, berdasarkan apa yang telah dilakukan sebelum tahap perencanaan oleh pendidik model ternyata masih banyak kekurangan, terutama perangkat pembelajaran yang disusun oleh pendidik model sehingga pada tahap perencanaan banyak yang harus direvisi/diperbaiki. Sesuai dengan hasil pada saat perencanaan bahwa yang perlu direvisi adalah rencana pelaksanaan pembelajaran dan lembar kerja peserta didik. Bagian rencana pelaksanaan pembelajaran yang perlu dilakukan revisi adalah pada bagian indikator pembelajaran, tujuan pembelajaran, materi pembelajaran dan LKS yang harus mencermikan pembelajaran berbasis inkuiri. Revisi tersebut berdasarkan dari masukan pendidik-pendidik yang berkompeten di bidang tersebut. Adapun pertimbangan mengapa harus dilakukan revisi/perbaikan rencana pelaksanaan pembelajaran yang diusulkan oleh pendidik model yaitu (1) ketidaksesuaian antara kompetensi dasar, indikator pembelajaran dan tujuan pembelajaran. (2) materi yang ingin disampaikan terlalu banyak untuk satu kali pertemuan, sehingga hanya diambil sebagian materi yaitu mengenai hukum I dan II Newton dengan alasan bahwa materi yang diajarkan tersebut lebih detail dan mendalam. Ternyata apa yang telah dilakukan pada tahap ini sangat menentukan pada saat melakukan tahap do (pelaksanaan) di kelas.

Tahap do merupakan tahap kedua setelah dilakukan perencanaan. Pada tahap ini pendidik model mengajar di kelas dan diamati oleh observer. Kegiatan pembelajaran yang dilaksanakan berdasarkan apa yang telah dilakukan pada tahap perencanaan. Kondisi peserta didik yang belum pernah bertatap muka sebelumnya merupakan suatu tantangan yang besar pada saat mengajar. Hal ini tentunya sangat berpengaruh pada proses kegiatan belajar mengajar terutama mengenai interaksi pendidik model dengan peserta didik. Selain itu, sifat dan karakteristik peserta didik yang belum dikenal oleh pendidik model merupakan faktor lain yang membuat pendidik model tidak tahu bahwa pengelompokkan peserta didik sudah baik atau belum karena hanya melihat tes awal peserta didik. Dan juga, karena pendidik model merupakan bukan pendidik di sekolah tersebut cendrung membuat peserta didik tidak mau mendengarkan sepenuhnya apa yang disampaikan oleh pendidik model sehingga proses pembelajaran tidak begitu efektif (Satriawan, 2015).

Pada saat pembelajaran dimulai, ada beberapa hambatan yang muncul diantaranya yaitu listrik yang diperlukan untuk menyampaikan materi melalui LCD tidak dapat digunakan. Hal ini jelas membuat pendidik model harus keluar dari apa yang telah direncanakan. Beberapa animasi yang harus ditampilkan melalui LCD tidak dapat disampaikan sehingga pendidik model hanya dapat menceritakannya dan materi yang seharusnya disampaikan melalui LCD akhirnya disampaikan melalui papan tulis. Hal ini tentunya berdampak pada efisiensi waktu, karena waktu merupakan sesuatu yang sensitif tentu saja berpengaruh juga pada pendidik model dimana apa yang sudah disetting dan seharusnya - akan disampaikan oleh pendidik model tidak semua terlaksana dan tersampaikan. Selain permasalahan di atas terdapat juga beberapa kesalahan dari pendidik model yaitu mengenai eksperimen sederhana yang bertujuan untuk mengetahui hubungan antara gaya, massa dan percepatan benda pada hukum II Newton secara kualitatif. Letak kesalahannya adalah di beberapa kelompok membuat alat yang digunakan sebagai mainan sehingga hanya beberapa peserta didik saja yang serius mengikuti eksperimen sampai selesai.

Dan berdasarkan hasil evaluasi pada tabel hasil belajar peserta didik di atas, untuk siklus I menunjukkan bahwa hanya $60 \%$ peserta didik memperoleh nilai di atas KKM sedangkan $40 \%$ tidak mencapai KKM. Hal ini dapat diartikan bahwa dari 
25 peserta didik yang mengikuti proses kegiatan belajar mengajar terdapat 15 peserta didik telah mencapai KKM sedangkan yang tidak mencapai KKM 10 orang. Jika dilihat sepintas berdasarkan hasil evaluasi pembelajaran yang dilakukan ketuntasan peserta didik secara klasikal belum tercapai dikarenakan ketuntasan klasikal berada di bawah $85 \%$. Indikator ketuntasan secara klasikal apabila peserta didik dalam kelas mencapai nilai di atas KKM > 85\% (Arikunto, 2006).

Tahap refleksi merupakan tahap akhir yang dilakukan pada saat melaksanakan kegiatan PPL yang berbasis lesson study. Semua observer yang mengamati jalannya kegiatan pembelajaran akan menyampaikan temuan-temuannya mengenai akvitas peserta didik dan kejanggalan-kejanggalan yang dapat mempengaruhi jalannya proses pembelajaran. Dengan dilakukannya tahap ini, pendidik model akan tahu dengan jelas mengenai hal-hal yang tidak teramati oleh pendidik model dan apa yang sebenarnya terjadi saat proses pembelajaran berlangsung. Dan berdasarkan hasil observasi yang dilakukan oleh beberapa pengamat, $90 \%$ observer mengatakan bahwa faktor alam yaitu situasi yang cukup panas ketika pelaksanaan pembelajaran sangat mempengaruhi minat belajar peserta didik dimana peserta didik tidak sepenuhnya konsentrasi memperhatikan dan mengikuti proses pembelajaran. $\mathrm{Hal}$ ini tentu saja sangat berdampak pada interaksi peserta didik dengan pendidik model, dimana peserta didik cendrung bersikap acuh tak acuh dan selalu ingin meneiptakan suasana bermain dan pada akhirnya apa yang dijelaskan oleh pendidik model tidak sepenuhnya diperhatikan (Satriawan, 2015). Namun, selain dari faktor alam tersebut ada juga dari faktor yang berasal dari pendidik model itu sendiri. Observer lainnya mengatakan bahwa kesalahan terbesar yang dilakukan oleh pendidik model yaitu belum nampaknya pembelajaran berbasis inkuiri sehingga pembelajaran tidak sesuai dengan tahapan yang telah direncanakan, sehingga perlu dilakukan perencanaan ulang sesuai denga hasil refleksi untuk melanjutkan ke siklus II.

Berdasarkan hasil observasi dari obeserver dapat dikatakan bahwa pada kegiatan siklus II menunjukkan dari keseluruhan tahap (plan, do dan refleksi) yang dilakukan sudah baik. Hal ini dapat dilihat dari kemampuan pendidik model telah mampu melaksanakan pembelajaran sesuai dengan yang direncanakan. Dengan kata lain bahwa pendidik model telah mampu menunjukkan profesionalitasnya. Hal ini senada dengan yang dikemukakan oleh Walker (2005) menyatakan bahwa lesson study adalah suatu pengembangan profesional guru. Lewis (2002) menyebutkan bahwa lesson study merupakan gagasan yang sederhana. Jika guru ingin meningkatkan instruksi dalam pembelajaran, maka guru haruslah bekerja sama dengan guru lainnya dalam merencanakan, mengamati, dan proses refleksi. Selain itu, terlihat bahwa pembelajaran telah nampak menggunakan metode inkuiri dan berjalan dengan lancar. Hal ini dapat dilihat bahwa peserta didik yang mampu menyelidiki dan permasalahan yang diberikan oleh pendidik. Sesuai dengan yang dikemukakan oleh Ju-Ling Shih, dkk. (2010) mengatakan "Inquiry Based Learning is a concept which encourages teachers to allow earners to get in touch with authentic situations, and to explore and to solve problems that are analogs to real life" yang artinya pembelajaran inkuiri adalah suatu konsep yang mendorong guru untuk memberikan kesempatan pebelajar untuk memperoleh ketrampilan dengan menyajikan situasi nyata, dan untuk menyelidiki dan menyelesaikan masalah yang berkaitan dengan kehidupan nyata

Dan berdasarkan data hasil belajar peserta didik pada siklus II menunjukkan bahwa hanya $92 \%$ peserta didik memperoleh nilai di atas KKM sedangkan $8 \%$ tidak mencapai KKM. Hal ini dapat diartikan bahwa dari 25 peserta didik yang mengikuti proses kegiatan belajar mengajar terdapat 23 peserta didik telah mencapai KKM sedangkan yang tidak mencapai KKM hanya 2 orang. Jika dilihat sepintas berdasarkan hasil evaluasi pembelajaran yang dilakukan ketuntasan peserta didik secara klasikal telah tercapai dikarenakan ketuntasan klasikal berada di atas $85 \%$. Indikator ketuntasan secara klasikal apabila peserta didik dalam kelas mencapai nilai di atas KKM > 85\% (Arikunto, 2006).

\section{PENUTUP}

\section{Simpulan}

Berdasarakan hasil penelitian menunjukkan bahwa terjadi peningkatan hasil belajar peserta didik dari siklus I ke siklus II pada pembelajaran yang menerapkan kegiatan lesso study berbasis inkuiri. Selain itu berdasarkan hasil observasi dari observer menunjukan bahwa pembelajaran fisika melalui lesson study berbasis inkuiri mampu meningkatkan kemampuan mengajar pendidik.

\section{DAFTAR PUSTAKA}

Alberta. 2003. Learning and Teaching Resources Branch. Focus on inquiry: a teacher's guide to implementing inquiry-based learning.

Arikunto S, 2006. Prosedur Penelitian Suatu Pendekatan Praktik, Ed Revisi VI. Penerbit PT Rineka Cipta: Jakarta.

Bell, R., L. Smetana, and I. Binns. 2005. Simplifying inquiry instruction. The Science Teacher 72(7): 30-34

Fernandez, C; Yoshida, M; Chokshi, S and Cannon, J. 2001. An Overview of Lesson Study, ppt. online 1srg@columbia.edu, www.tc.edu/ lessonstudy

Fernandez, C dan Yoshida, M 2004. Lesson Study: A Janese Approach to Improveing Mathematics Teaching and Learning. 
London: Lawlence Erlbaum Associated, Inc.

Garfield, J. 2006. Exploring the Impact of Lesson Study on Developing Effective Statistics Curriculum.

(Online). (http://www.statauckland.ac.nz), diakses tanggal 20 April 2014.

Khan, Wali. 2012. Inquiry-Based Teaching in Mathematics Classroom in a Lower Secondary School Of Karachi, International Journal of Academic Research in Progressive Education and Development, Vol. 1, No. 2

Kuhlthau, C.C., Maniotes, L.K., \& Caspari, A.K. (2007). Guided Inquiry. USA: British Library Cataloguing.

Marsigit. 2007. Mathematics Teachers" Professional Development through Lesson Study in Indonesia. Eurasia Journal of Mathematics, Science \& Technology Education, 2007, 3(2), 141-144. (Online). (http://ejmste.com)

Munandar, Utami. 1995. Mengembangkan Kreativitas anak Berbakat. Jakarta: Gramedia.

Lewis, C.S. 2002. Lesson Study: A Handbook of Teacher-Led Instuctional Change. Philadelphia, PA: Rechool, Inc. Research for Better Schools.

Saito, E., Imansyah, H. dan Ibrohim. 2005. Penerapan Studi Pembelajaran di Indonesia:- Studi Kasus dari IMSTEP. Jurnal Pendidikan "Mimbar Pendidikan", No.3. Th. XXIV: 24-32.
Satriawan, M. (2015, May 25). Learning Physics Through The Cooperative Model Of The Type Of Tai Observed From Metacognitive Skills Against Cognitive Learning Outcomes. http://doi.org/10.17605/OSF.IO/YJX5N

Satriawan, M. (2015, January 24). Pembelajaran Fisika Melalui Strategi Reciprocal Teaching Ditinjau Dari Sikap Ilmiah Terhadap Hasil Belajar Kognitif Peserta Didik. http://doi.org/10.17605/OSF.IO/673ZJ

Satriawan, Muhammad,and Rosmiati 2014. "Pengembangan Perangkat Pembelajaran Fisika Yang Berorientasi Pada Model Pengajaran Langsung Pada Materi Entropi Dan Perubahannya". Open Science Framework. 22. doi:10.17605/OSF.IO/GNES9.

Sutopo dan Ibrohim. 2006. Pengalaman IMSTEP dalam Implementasi Lesson Study. Makalah. Disajikan dalam Pelatihan kemitraan LPTK-Sekolah dalam rangka peningkatan mutu Pendidikan MIPA, di Hotel Yogyakarta, 27-29 Juli 2006.

Walker, J. S. 2005. UWEC Math Dept. Journal of Lesson Studies. (Online). (http://uwec.edu),

Wang-Iverson, Patsy. 2002. Why lesson study? http://www.rbs.org/lesson study/conference/2002/papers/wong.htm

Yoshida, M. 2002. Developing Effective Use of the Blackboard through Lesson Study. http://www.rbs.org/lesson_study/confenren ce/2002/ paper/Yoshida_blacboard.shtml 